\title{
Evaluasi Bangunan 41 Lantai Tahan Gempa dengan Analisis Dinamik Spektrum Respons Ragam
}

\author{
Mansyur \\ Program Studi Teknik Sipil Fakultas Sains dan Teknologi USN Kolaka \\ mansyurusn14@gmail.com
}

\begin{abstract}
Abstrak
Indonesia merupakan salah satu negara yang memiliki intensitas gempa yang tinggi. Oleh karena itu, dalam perencanaan struktur bangunan perlu adanya studi yang lebih mendalam tentang analisis dan perencanaan struktur tahan gempa. Penelitian ini bertujuan untuk mengetahui hasil analisis bangunan 41 lantai yang ditinjau di 4 kota Indonesia berdasarkan SNI 03-1726-2012 dengan program komputer. Penelitian ini merupakan penelitian berbasis komputer, dimana bangunan 41 lantai untuk analisis dinamik spektrum respons ragam. Studi kasus bangunan dilakukan pada empat kota di Indonesia yakni Aceh, Kolaka, Yogyakarta, dan Padang. Hasil penelitian menunjukkan bahwa pada peninjauan bangunan dengan analisis dinamik spektrum respon ragam, nilai base shear dan displacement tidak begitu berpengaruh pada besarnya intensitas gempa jika dijadikan perbandingan dengan kota lain akibat lebih besarnya beban lain dibandingkan beban gempa.
\end{abstract}

Kata kunci : bangunan, gempa, analisis dinamik, spektrum respon ragam

\section{Pendahuluan}

Indonesia merupakan salah satu negara yang memiliki intensitas gempa yang tinggi, hal ini disebabkan posisi geografis Indonesia. Indonesia terletak pada jalur cincin api (Ring of Fire) kawasan pasifik dan pertemuan tiga lempeng tektonik besar dunia, yaitu lempeng IndoAustralia, lempeng Eurasia dan lempeng Pasifik. Pergerakan ketiga lempeng tersebut dan dua lempeng lain yaitu Laut Philipina dan Carolina mengakibatkan terjadi gempa bumi pada daerah-daerah pertemuan antar lempeng dan menimbulkan sesar-sesar regional yang menjadi pusat gempa.

Pada perencanaan bangunan, parameter gempa bumi yang langsung mempengaruhi perencanaan adalah percepatan tanah yang ditimbulkan gelombang seismic yang bekerja pada massa bangunan. Kedalaman pusat gempa bumi, jarak episenter ke daerah yang dituju, sistem pondasi, massa dan geometri bangunan dan lain sebagainya. Sehingga pengaruh gempa terhadap sebuah bangunan tergantung wilayahnya (Helmy \& Iskandarsyah. 2009).

Menurut (Budiono B \& Supriatna L. 2011) dalam perencanaan struktur bangunantahan gempa diperlukan standar danperaturan-peraturan perencanaanbangunan untuk menjaminkesalamatanpenghuni serta menghindari danmeminimalisasi kerusakan struktur dankorban jiwa terhadap gempa bumi yang sering terjadi. Kegagalan strukturbangunan bisa disebabkan antara lain olehkesalahan perhitungan dalam perencanaan,tidak sesuainya perencanaan denganimplementasi pelaksanaan pekerjaan dilapangan, perubahan fungsi bangunan,bencana alam seperti gempa bumi kuat danlainnya (Sayed A.F., dkk. 2018).

Menurut (Christiawan I, dkk. 2008), evaluasi kinerja struktur gedung dapatdilakukan dengan cara menganalisiskinerja batas ultimum dan kinerja bataslayan berdasarkan SNI 031726-2002. Dihimpun dari Badan Standardisasi Nasional (BSN). 2012, SNI 03-1726-2012 yang berisi tentang pedoman tata caraperencanaan ketahanan gempa untukstruktur bangunan gedung dan non-gedungyang merupakan revisi dari SNI 03-1726-2002. Pedoman SNI 03- 
1726-2012 telahmenggunakan peta riwayat gempa terbarusejak 2010 sehingga bangunan gedungyang dibangun sebelum tahun 2010 perludilakukan evaluasi struktur untukmengetahui keamanan struktur menurutstandar yang baru. Perbedaan pedomanperencanaan gedung untuk ketahanangempa SNI 03-1726-2002 dan SNI 03-1726-2012, yaitu desain percepatanspektral gempa SNI 03-1726-2012 dibeberapa wilayah Indonesia mengalamikenaikan pada jenis kelas situs tanahsedang dan tanah keras dan penurunanpada jenis kelas situs tanah lunak (Afriadi Y \& Satyarno I. 2013).

Secara umum analisis gempa dibagi dua yakni analisis gempa statik dan analisis gempa dinamis. Pada bangunan yang sangat tinggi, tidak beraturan, bertingkat banyak serta bangunan yang memerlukan ketelitian yang sangat besar digunakan perencanaan analisis dinamik, yang terdiri dari analisis ragam respon spektrum dan analisis dinamik riwayat waktu (Agus Hariyanto. 2011). Analisis dinamik untuk perancangan struktur tahan gempa dilakukan jika diperlukan evaluasi yang lebih akurat dari gaya-gaya gempa yang bekerja pada struktur, serta untuk mengetahui perilaku dari struktur akibat pengaruh gempa Agus (Purnomo W. 2015).

Pada struktur bangunantingkat tinggi atau struktur dengan bentuk ataukonfigurasi yang tidak teratur. Analisis dinamikdapat dilakukan dengan cara elastis maupun inelastic (Bowles. 1991). Pada cara elastis dibedakan AnalisisRagam Riwayat Waktu (Time History ModalAnalysis), dimana pada cara ini diperlukanrekaman percepatan gempa dan Analisis RagamSpektrum Respon (Respons Spectrum ModalAnalysis), dimana pada cara ini respons maksimumdari tiap ragam getar yang terjadi didapat dariRespons spektrum Rencana (Design Spectra) (Elliza, Ismailah Nur. 2013). Dalam SNI 03-1726-2012 dinyatakan bahwa untuk struktur gedung beraturan dapat digunakan metodeanalisis statik ekivalen untuk perencanaan gempa. Sedangkan analisis dinamik dapatdilakukan untuk jenis bangunan apapun, tetapi merupakan suatu keharusan untukbangunan tidak beraturan sesuai definisi dalam SNI 031726-2012.

Salah satu syarat suatu gedung dikatakan gedung beraturan berdasarkan SNI 03-17262012 yaitu tinggi struktur gedung diukur dari taraf penjepitan lateral tidak lebih dari 12 tingkat. Pembatasan ini dilakukan karena hasil analisis statik ekivalen kurang presisi untuk struktur yang lebih dari 12 tingkat. Oleh karena itu diperlukan analisis secara dinamik untuk memperoleh respons bangunan yang lebih mendekati respons struktur yang sebenarnya ketika terjadi gempa

\section{Metode Penelitian}

Jenis penelitian ini adalah penelitian berbasis computer, dimana bangunan 41 lantai untuk analisis dinamik spektrum respons ragam. Model bangunan 41 lantai ditinjau di 4 kota yang berbeda. Variasi beban gempa diperoleh dari 4 lokasi yang berbeda antara lain, Kota Aceh, Kota Kolaka, Kota Yogyakarta dan Kota Padang. Empat lokasi tersebut dianggap dapat mewakili kondisi beban gempa lemah, sedang dan kuat di Indonesia.

Dengan variasi-variasi tersebut, diperoleh 4 kemungkinan beban gempa yang kemudian dinyatakan dalam bentuk grafik spektrum respons gempa agar dapat digunakan pada analisis. Grafik spektrum respons gempa diperoleh dari situs www.puskim.pu.go.idyang telah mengacu pada peta gempa Indonesia tahun 2010 dan SNI 03-1726-2012.

\subsection{Pengolahan data}

Langkah-langkah yang dilakukan untuk pengolahan data model bangunan 41 lantai adalah sebagai berikut :

Adapun langkah-langkah dalam analisis ini sebagai berikut:

a. Menggambar Portal 3D menggunakan program SAP 2000 v.20 sebagai langkah awal untuk memasukan data yang akan dianalisis oleh program tersebut, 
b. Menghitung manual jumlah beban mati, beban hidup, beban terpusat yang membebani gedung tersebut,

c. Memasukkan semua beban yang bekerja ke dalam program,

d. Memasukan data beban gempa kedalam program untuk dianalisis,

e. Memasukan kombinasi beban ke dalam program,

f. Menganalisis data dengan program tersebut, kemudian dengan mengecek keamanan struktur dan membaca hasil analisis,

g. Analisis dilakukan berdasarkan SNI 03-1726-2012,

h. Melakukan analisis perencanaan di 4 kota Indonesia,

i. Kesimpulan berupa bangunan yang dikaji memenuhi persyaratan gempa atau tidak

Dalam Pasal 6.4 SNI-1726-2012 ditentukan ketentuan-ketentuan dalam membuat grafik spektrum respons desain. Ketentuan-ketentuan tersebut antara lain:

1. Untuk perioda yang lebih kecil dari To, spektrum respons percepatan desain $S_{a}$ harus diambil dari persamaan berikut.

$$
S_{a}=S_{D S}\left(0,4+0,6 \frac{T}{T_{o}}\right)
$$

2. Untuk perioda lebih besar dari atau sama dengan $T$ dan lebih kecil dari atau sama dengan $T s$, spektrum respons percepatan desain $S a$ sama dengan $S_{\mathrm{DS}}$.

3. Untuk perioda lebih besar dari $T s$, spektrum respons percepatan desain $S$ a diambil berdasarkan persamaan berikut.

Keterangan:

$$
S_{a}=\frac{S_{D 1}}{T}
$$

$S_{\mathrm{DS}}=$ parameter respons spektral percepatan desain pada periode pendek.

$S_{\mathrm{D} 1}=$ parameter respons spektral percepatan desain pada periode 1 detik

$T$ = perioda getar fundamental struktur

$$
\begin{aligned}
& T_{0}=0,2 \frac{S_{D 1}}{S_{D S}} \\
& T_{S}=\frac{S_{D 1}}{S_{D S}}
\end{aligned}
$$

Pada SAP2000 analisis response spectrum dilakukan dengan input grafik spektrum respons desain. Hal yang harus diperhatikan dalam input pada SAP2000 adalah skala input/faktor skala. Skala input untuk beban gempa response spectrum adalah sebagai berikut.

$$
f=\frac{I_{e}}{R}
$$

Keterangan:

$\mathrm{f}=$ faktor skala

$I_{e}=$ faktor keutamaan gempa

$\mathrm{R}=$ koefesien modifikasi respons

Nilai faktor skala dinyatakan dalam percepatan gravitasi bumi (g) yaitu 9,81 m/detik.

\section{HASIL DAN PEMBAHASAN}




\subsection{Data Gempa}

\section{Parameter Respons Spektral}

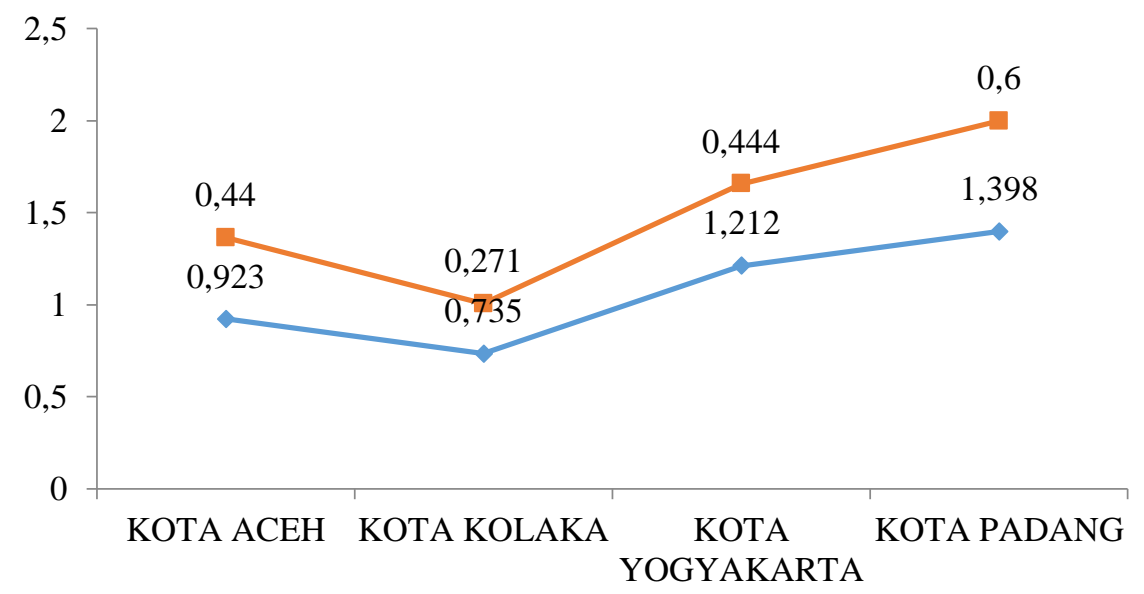

Gambar1 Parameter Respons Spektral Tiap Kota

\subsection{Data Bangunan}

a. Kategori Resiko =2, Untuk Gedung Apartemen

b. Faktor Keutamaan (Ie) =1, Untuk Gedung Apartemen

c. Klasifikasi Situs = (SD) Tanah Sedang

d. Struktur = Beton Bertulang

e. Struktur ditentukan sebagai rangka beton bertulang pemikul momen biasa didapat nilai $\mathrm{R}=3$.

f. Periode fundamental pendekatan $\mathrm{Ct}=0,0466$ dan $\mathrm{x}=0,9$

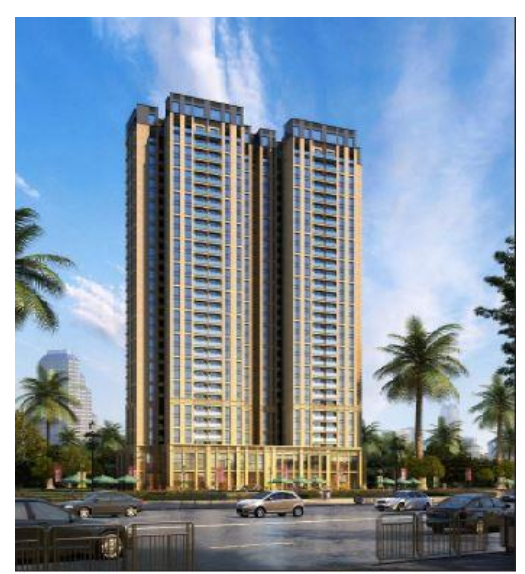

Gambar 2. Bangunan 41 Lantai

\subsection{Analisis Perhitungan}

a. Kota Aceh

Analisis spektrum respons ragam dilakukan dengan metode kombinasi kuadrat lengkap (Complete Quadratic Combination / CQC) dengan input $S s=0,923 ; S 1=0,440$ sesuai pada subbab 4.2.1. Penggunaan metode CQC karena memiliki waktu getar alami yang berdekatan, yaitu selisihnya kurang dari $15 \%$. 
Untuk nilai akhir respons dinamik struktur gedung terhadap pembebanan gempa nominal akibat pengaruh gempa rencana dalam suatu arah tertentu bedasarkan SNI 03-1726-2012 pasal 7.9.4.1, tidak boleh kurang dari $85 \%$ nilai gaya lateral statik ekivalen

b. Kota Kolaka

Analisis spektrum respons ragam dilakukan dengan metode kombinasi kuadrat lengkap (Complete Quadratic Combination / CQC) dengan input $S s=0,735 ; S 1=0,271$ sesuai pada subbab 4.2.1. Penggunaan metode CQC karena memiliki waktu getar alami yang berdekatan, yaitu selisihnya kurang dari $15 \%$.

Untuk nilai akhir respons dinamik struktur gedung terhadap pembebanan gempa nominal akibat pengaruh gempa rencana dalam suatu arah tertentu bedasarkan SNI 03-1726-2012 pasal 7.9.4.1, tidak boleh kurang dari $85 \%$ nilai gaya lateral statik ekivalen.

c. Kota Yogyakarta

Analisis spektrum respons ragam dilakukan dengan metode kombinasi kuadrat lengkap (Complete Quadratic Combination / CQC) dengan input $S s=1,212 ; S 1=0,444$ sesuai pada subbab 4.2.1. Penggunaan metode CQC karena memiliki waktu getar alami yang berdekatan, yaitu selisihnya kurang dari $15 \%$.

Untuk nilai akhir respons dinamik struktur gedung terhadap pembebanan gempa nominal akibat pengaruh gempa rencana dalam suatu arah tertentu bedasarkan SNI 03-1726-2012 pasal 7.9.4.1, tidak boleh kurang dari $85 \%$ nilai gaya lateral statik ekivalen.

d. Kota Padang

Analisis spektrum respons ragam dilakukan dengan metode kombinasi kuadrat lengkap (Complete Quadratic Combination / CQC) dengan input $S s=1,398 ; S 1=0,600$ sesuai pada subbab 4.2.1. Penggunaan metode CQC karena memiliki waktu getar alami yang berdekatan, yaitu selisihnya kurang dari $15 \%$.

Untuk nilai akhir respons dinamik struktur gedung terhadap pembebanan gempa nominal akibat pengaruh gempa rencana dalam suatu arah tertentu bedasarkan SNI 03-1726-2012 pasal 7.9.4.1, tidak boleh kurang dari $85 \%$ nilai gaya lateral statik ekivalen.

\subsection{Hasil Analisis}

Hasil analisis dari analisis gempa dengan cara statik ekivalen yang akan ditinjau adalah displacement/simpangan antar lantai dan gaya geser tiap lantai akibat gempa.

1. Simpangan Antar Lantai (Displacements)

a. $\operatorname{Arah} X$

Tabel 1. Hasil Analisis Displacements Bangunan 41 Lantai Arah X

\begin{tabular}{|c|c|c|c|c|c|c|c|c|}
\hline \multicolumn{4}{|c|}{} & \multicolumn{4}{c|}{$\begin{array}{c}\text { Simpangan Antar Lantai } \\
\text { Tiap Kota }(\Delta)\end{array}$} & $\begin{array}{c}\text { Simpangan } \\
\text { Antar Lantai } \\
\text { Ijin }(\Delta \mathbf{a})\end{array}$ \\
\hline Joint & Lantai & Output Case & $\mathbf{Z}$ & $\begin{array}{c}\text { Kota } \\
\text { Aceh }\end{array}$ & $\begin{array}{c}\text { Kota } \\
\text { Kolaka }\end{array}$ & $\begin{array}{c}\text { Kota } \\
\text { Yogyakarta }\end{array}$ & $\begin{array}{c}\text { Kota } \\
\text { Padang }\end{array}$ & \\
\hline Text & Text & Text & $\mathrm{m}$ & $\mathrm{m}$ & $\mathrm{m}$ & $\mathrm{m}$ & $\mathrm{m}$ & $\mathrm{m}$ \\
\hline $\mathbf{1 4 5 1}$ & Atap & COM.MAX & 122,55 & 0,003 & 0,003 & 0,003 & 0,003 & 0,045 \\
\hline $\mathbf{1 4 5 0}$ & 41 & COM.MAX & 119,65 & 0,000 & 0,000 & 0,000 & 0,000 & 0,045 \\
\hline $\mathbf{1 4 4 9}$ & 40 & COM.MAX & 116,75 & 0,006 & 0,006 & 0,006 & 0,006 & 0,045 \\
\hline $\mathbf{1 4 4 8}$ & 39 & COM.MAX & 113,85 & 0,009 & 0,009 & 0,009 & 0,009 & 0,045 \\
\hline $\mathbf{1 4 4 7}$ & 38 & COM.MAX & 110,95 & 0,005 & 0,005 & 0,005 & 0,005 & 0,045 \\
\hline
\end{tabular}


https://jurnal.unsulbar.ac.id/index.php/saintifik

\begin{tabular}{|c|c|c|c|c|c|c|c|c|}
\hline 1446 & 37 & COM.MAX & 108,05 & 0,002 & 0,002 & 0,002 & 0,002 & 0,045 \\
\hline 1445 & 36 & COM.MAX & 105,15 & $-0,002$ & $-0,002$ & $-0,002$ & $-0,002$ & 0,045 \\
\hline 1444 & 35 & COM.MAX & 102,25 & $-0,002$ & $-0,002$ & $-0,002$ & $-0,002$ & 0,045 \\
\hline 1443 & 34 & COM.MAX & 99,35 & $-0,001$ & $-0,001$ & $-0,001$ & $-0,001$ & 0,045 \\
\hline 1442 & 33 & COM.MAX & 96,45 & 0,002 & 0,002 & 0,002 & 0,002 & 0,045 \\
\hline 1441 & 32 & COM.MAX & 93,55 & 0,004 & 0,004 & 0,004 & 0,004 & 0,045 \\
\hline 1440 & 31 & COM.MAX & 90,65 & 0,004 & 0,004 & 0,004 & 0,004 & 0,045 \\
\hline 1439 & 30 & COM.MAX & 87,75 & 0,003 & 0,003 & 0,003 & 0,003 & 0,045 \\
\hline 1438 & 29 & COM.MAX & 84,85 & 0,002 & 0,002 & 0,002 & 0,002 & 0,045 \\
\hline 1437 & 28 & COM.MAX & 81,95 & 0,002 & 0,002 & 0,002 & 0,002 & 0,045 \\
\hline 1436 & 27 & COM.MAX & 79,05 & 0,003 & 0,003 & 0,003 & 0,003 & 0,045 \\
\hline 1435 & 26 & COM.MAX & 76,15 & 0,004 & 0,004 & 0,004 & 0,004 & 0,045 \\
\hline 1434 & 25 & COM.MAX & 73,25 & 0,004 & 0,004 & 0,004 & 0,004 & 0,045 \\
\hline 1433 & 24 & COM.MAX & 70,35 & 0,003 & 0,003 & 0,003 & 0,003 & 0,045 \\
\hline 1432 & 23 & COM.MAX & 67,45 & 0,002 & 0,002 & 0,002 & 0,002 & 0,045 \\
\hline 1431 & 22 & COM.MAX & 64,55 & 0,002 & 0,002 & 0,002 & 0,002 & 0,045 \\
\hline 1430 & 21 & COM.MAX & 61,65 & 0,003 & 0,003 & 0,003 & 0,003 & 0,045 \\
\hline 1429 & 20 & COM.MAX & 58,75 & 0,003 & 0,003 & 0,003 & 0,003 & 0,045 \\
\hline 1428 & 19 & COM.MAX & 55,85 & 0,003 & 0,003 & 0,003 & 0,003 & 0,045 \\
\hline 1427 & 18 & COM.MAX & 52,95 & 0,003 & 0,003 & 0,003 & 0,003 & 0,045 \\
\hline 1426 & 17 & COM.MAX & 50,05 & 0,002 & 0,002 & 0,002 & 0,002 & 0,045 \\
\hline 1425 & 16 & COM.MAX & 47,15 & 0,002 & 0,002 & 0,002 & 0,002 & 0,045 \\
\hline 1424 & 15 & COM.MAX & 44,25 & 0,002 & 0,002 & 0,002 & 0,002 & 0,045 \\
\hline 1423 & 14 & COM.MAX & 41,35 & 0,002 & 0,002 & 0,002 & 0,002 & 0,045 \\
\hline 1422 & 13 & COM.MAX & 38,45 & 0,002 & 0,002 & 0,002 & 0,002 & 0,045 \\
\hline 1421 & 12 & COM.MAX & 35,55 & 0,002 & 0,002 & 0,002 & 0,002 & 0,045 \\
\hline 1420 & 11 & COM.MAX & 32,65 & 0,002 & 0,002 & 0,002 & 0,002 & 0,045 \\
\hline 1419 & 10 & COM.MAX & 29,75 & 0,002 & 0,002 & 0,002 & 0,002 & 0,045 \\
\hline 1418 & 9 & COM.MAX & 26,85 & 0,002 & 0,002 & 0,002 & 0,002 & 0,045 \\
\hline 1417 & 8 & COM.MAX & 23,95 & 0,002 & 0,002 & 0,002 & 0,002 & 0,045 \\
\hline 1416 & 7 & COM.MAX & 21,05 & 0,002 & 0,002 & 0,002 & 0,002 & 0,045 \\
\hline 1415 & 6 & COM.MAX & 18,15 & 0,003 & 0,003 & 0,003 & 0,003 & 0,045 \\
\hline 1414 & 5 & COM.MAX & 15,25 & 0,003 & 0,003 & 0,003 & 0,003 & 0,045 \\
\hline 1413 & 4 & COM.MAX & 12,35 & 0,003 & 0,003 & 0,003 & 0,003 & 0,045 \\
\hline 1412 & 3 & COM.MAX & 9,45 & 0,004 & 0,004 & 0,004 & 0,004 & 0,069 \\
\hline 1411 & 2 & COM.MAX & 4,95 & 0,004 & 0,004 & 0,004 & 0,004 & 0,077 \\
\hline 1410 & 1 & COM.MAX & $-0,05$ & 0,003 & 0,003 & 0,003 & 0,003 & 0,089 \\
\hline 1409 & B3 & COM.MAX & $-5,85$ & 0,001 & 0,001 & 0,001 & 0,001 & 0,074 \\
\hline 16 & B2 & COM.MAX & $-10,65$ & 0,000 & 0,000 & 0,000 & 0,000 & 0,055 \\
\hline 1408 & B1 & COM.MAX & $-14,25$ & 0,000 & 0,000 & 0,000 & 0,000 & 0,000 \\
\hline
\end{tabular}




\section{Simpangan Antar Lantai Arah X Tiap Kota}

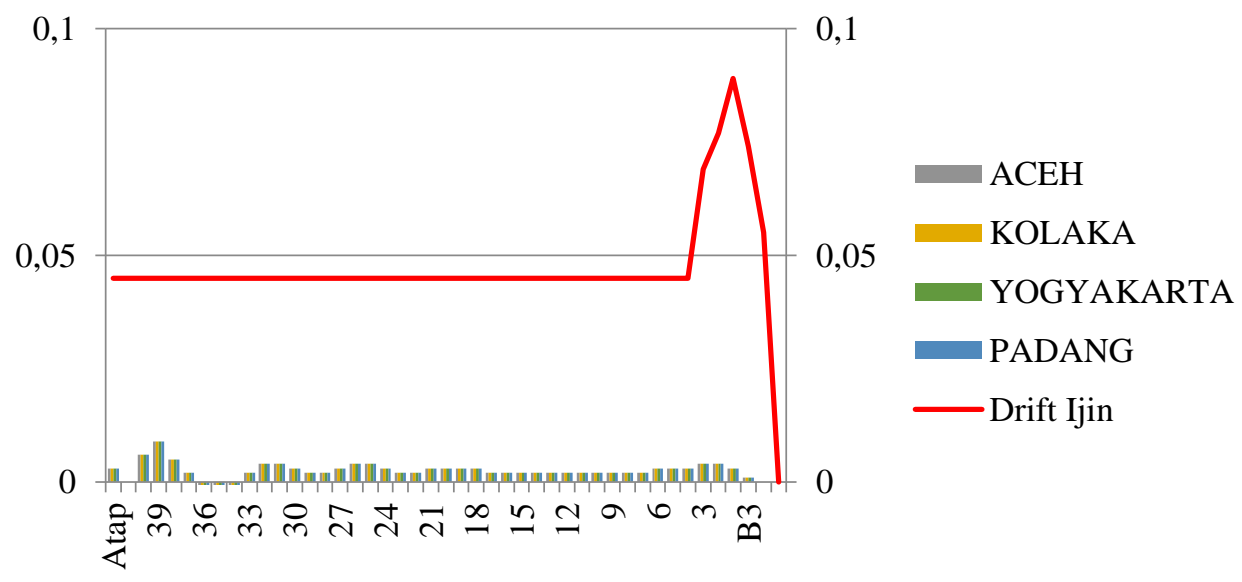

Gambar 3. Simpangan Antar Lantai Arah X Bangunan 41 Lantai

b. Arah Y

Tabel 2. Hasil Analisis Displacements Bangunan 41 Lantai Arah Y

\begin{tabular}{|c|c|c|c|c|c|c|c|c|}
\hline \multicolumn{3}{|c|}{ TABLE: Joint Displacements } & \multicolumn{5}{c|}{$\begin{array}{c}\text { Simpangan Antar Lantai } \\
\text { Tiap Kota }(\Delta)\end{array}$} & $\begin{array}{c}\text { Simpangan } \\
\text { Antar Lantai } \\
\text { Ijin }(\Delta \mathbf{a})\end{array}$ \\
\hline Joint & Lantai & Output Case & $\mathrm{Z}$ & $\begin{array}{c}\text { Kota } \\
\text { Aceh }\end{array}$ & $\begin{array}{c}\text { Kota } \\
\text { Kolaka }\end{array}$ & $\begin{array}{c}\text { Kota } \\
\text { Yogyakarta }\end{array}$ & $\begin{array}{c}\text { Kota } \\
\text { Padang }\end{array}$ & \\
\hline Text & Text & Text & $\mathrm{m}$ & $\mathrm{m}$ & $\mathrm{m}$ & $\mathrm{m}$ & $\mathrm{m}$ & $\mathrm{m}$ \\
\hline $\mathbf{1 4 5 1}$ & Atap & COM.MAX & 122,55 & $-0,001$ & $-0,001$ & $-0,001$ & $-0,001$ & 0,045 \\
\hline $\mathbf{1 4 5 0}$ & 41 & COM.MAX & 119,65 & $-0,002$ & $-0,002$ & $-0,002$ & $-0,002$ & 0,045 \\
\hline $\mathbf{1 4 4 9}$ & 40 & COM.MAX & 116,75 & 0,000 & 0,000 & 0,000 & 0,000 & 0,045 \\
\hline $\mathbf{1 4 4 8}$ & 39 & COM.MAX & 113,85 & 0,003 & 0,003 & 0,003 & 0,003 & 0,045 \\
\hline $\mathbf{1 4 4 7}$ & 38 & COM.MAX & 110,95 & 0,001 & 0,001 & 0,001 & 0,001 & 0,045 \\
\hline $\mathbf{1 4 4 6}$ & 37 & COM.MAX & 108,05 & 0,000 & 0,000 & 0,000 & 0,000 & 0,045 \\
\hline $\mathbf{1 4 4 5}$ & 36 & COM.MAX & 105,15 & $-0,002$ & $-0,002$ & $-0,002$ & $-0,002$ & 0,045 \\
\hline $\mathbf{1 4 4 4}$ & 35 & COM.MAX & 102,25 & $-0,002$ & $-0,002$ & $-0,002$ & $-0,002$ & 0,045 \\
\hline $\mathbf{1 4 4 3}$ & 34 & COM.MAX & 99,35 & $-0,001$ & $-0,001$ & $-0,001$ & $-0,001$ & 0,045 \\
\hline $\mathbf{1 4 4 2}$ & 33 & COM.MAX & 96,45 & 0,000 & 0,000 & 0,000 & 0,000 & 0,045 \\
\hline $\mathbf{1 4 4 1}$ & 32 & COM.MAX & 93,55 & 0,000 & 0,000 & 0,000 & 0,000 & 0,045 \\
\hline $\mathbf{1 4 4 0}$ & 31 & COM.MAX & 90,65 & 0,000 & 0,000 & 0,000 & 0,000 & 0,045 \\
\hline $\mathbf{1 4 3 9}$ & 30 & COM.MAX & 87,75 & 0,001 & 0,001 & 0,001 & 0,001 & 0,045 \\
\hline $\mathbf{1 4 3 8}$ & 29 & COM.MAX & 84,85 & 0,001 & 0,001 & 0,001 & 0,001 & 0,045 \\
\hline $\mathbf{1 4 3 7}$ & 28 & COM.MAX & 81,95 & 0,001 & 0,001 & 0,001 & 0,001 & 0,045 \\
\hline $\mathbf{1 4 3 6}$ & 27 & COM.MAX & 79,05 & 0,001 & 0,001 & 0,001 & 0,001 & 0,045 \\
\hline $\mathbf{1 4 3 5}$ & 26 & COM.MAX & 76,15 & 0,001 & 0,001 & 0,001 & 0,001 & 0,045 \\
\hline $\mathbf{1 4 3 4}$ & 25 & COM.MAX & 73,25 & 0,001 & 0,001 & 0,001 & 0,001 & 0,045 \\
\hline $\mathbf{1 4 3 3}$ & 24 & COM.MAX & 70,35 & 0,001 & 0,001 & 0,001 & 0,001 & 0,045 \\
\hline $\mathbf{1 4 3 2}$ & 23 & COM.MAX & 67,45 & 0,002 & 0,002 & 0,002 & 0,002 & 0,045 \\
\hline $\mathbf{1 4 3 1}$ & 22 & COM.MAX & 64,55 & 0,002 & 0,002 & 0,002 & 0,002 & 0,045 \\
\hline $\mathbf{1 4 3 0}$ & 21 & COM.MAX & 61,65 & 0,001 & 0,001 & 0,001 & 0,001 & 0,045 \\
\hline $\mathbf{1 4 2 9}$ & 20 & COM.MAX & 58,75 & 0,001 & 0,001 & 0,001 & 0,001 & 0,045 \\
\hline $\mathbf{1 4 2 8}$ & 19 & COM.MAX & 55,85 & 0,000 & 0,000 & 0,000 & 0,000 & 0,045 \\
\hline
\end{tabular}


https://jurnal.unsulbar.ac.id/index.php/saintifik

\begin{tabular}{|c|c|c|c|c|c|c|c|c|}
\hline $\mathbf{1 4 2 7}$ & 18 & COM.MAX & 52,95 & 0,000 & 0,000 & 0,000 & 0,000 & 0,045 \\
\hline $\mathbf{1 4 2 6}$ & 17 & COM.MAX & 50,05 & 0,000 & 0,000 & 0,000 & 0,000 & 0,045 \\
\hline $\mathbf{1 4 2 5}$ & 16 & COM.MAX & 47,15 & 0,000 & 0,000 & 0,000 & 0,000 & 0,045 \\
\hline $\mathbf{1 4 2 4}$ & 15 & COM.MAX & 44,25 & 0,000 & 0,000 & 0,000 & 0,000 & 0,045 \\
\hline $\mathbf{1 4 2 3}$ & 14 & COM.MAX & 41,35 & 0,000 & 0,000 & 0,000 & 0,000 & 0,045 \\
\hline $\mathbf{1 4 2 2}$ & 13 & COM.MAX & 38,45 & 0,000 & 0,000 & 0,000 & 0,000 & 0,045 \\
\hline $\mathbf{1 4 2 1}$ & 12 & COM.MAX & 35,55 & 0,000 & 0,000 & 0,000 & 0,000 & 0,045 \\
\hline $\mathbf{1 4 2 0}$ & 11 & COM.MAX & 32,65 & 0,001 & 0,001 & 0,001 & 0,001 & 0,045 \\
\hline $\mathbf{1 4 1 9}$ & 10 & COM.MAX & 29,75 & 0,001 & 0,001 & 0,001 & 0,001 & 0,045 \\
\hline $\mathbf{1 4 1 8}$ & 9 & COM.MAX & 26,85 & 0,001 & 0,001 & 0,001 & 0,001 & 0,045 \\
\hline $\mathbf{1 4 1 7}$ & 8 & COM.MAX & 23,95 & 0,000 & 0,000 & 0,000 & 0,000 & 0,045 \\
\hline $\mathbf{1 4 1 6}$ & 7 & COM.MAX & 21,05 & 0,000 & 0,000 & 0,000 & 0,000 & 0,045 \\
\hline $\mathbf{1 4 1 5}$ & 6 & COM.MAX & 18,15 & 0,000 & 0,000 & 0,000 & 0,000 & 0,045 \\
\hline $\mathbf{1 4 1 4}$ & 5 & COM.MAX & 15,25 & 0,000 & 0,000 & 0,000 & 0,000 & 0,045 \\
\hline $\mathbf{1 4 1 3}$ & 4 & COM.MAX & 12,35 & 0,001 & 0,001 & 0,001 & 0,001 & 0,045 \\
\hline $\mathbf{1 4 1 2}$ & 3 & COM.MAX & 9,45 & 0,002 & 0,002 & 0,002 & 0,002 & 0,069 \\
\hline $\mathbf{1 4 1 1}$ & 2 & COM.MAX & 4,95 & 0,002 & 0,002 & 0,002 & 0,002 & 0,077 \\
\hline $\mathbf{1 4 1 0}$ & 1 & COM.MAX & $-0,05$ & 0,001 & 0,001 & 0,001 & 0,001 & 0,089 \\
\hline $\mathbf{1 4 0 9}$ & B3 & COM.MAX & $-5,85$ & 0,001 & 0,001 & 0,001 & 0,001 & 0,074 \\
\hline $\mathbf{1 6}$ & B2 & COM.MAX & $-10,65$ & 0,000 & 0,000 & 0,000 & 0,000 & 0,055 \\
\hline $\mathbf{1 4 0 8}$ & B1 & COM.MAX & $-14,25$ & 0,000 & 0,000 & 0,000 & 0,000 & 0,000 \\
\hline
\end{tabular}

\section{Simpangan Antar Lantai Arah Y Tiap Kota}

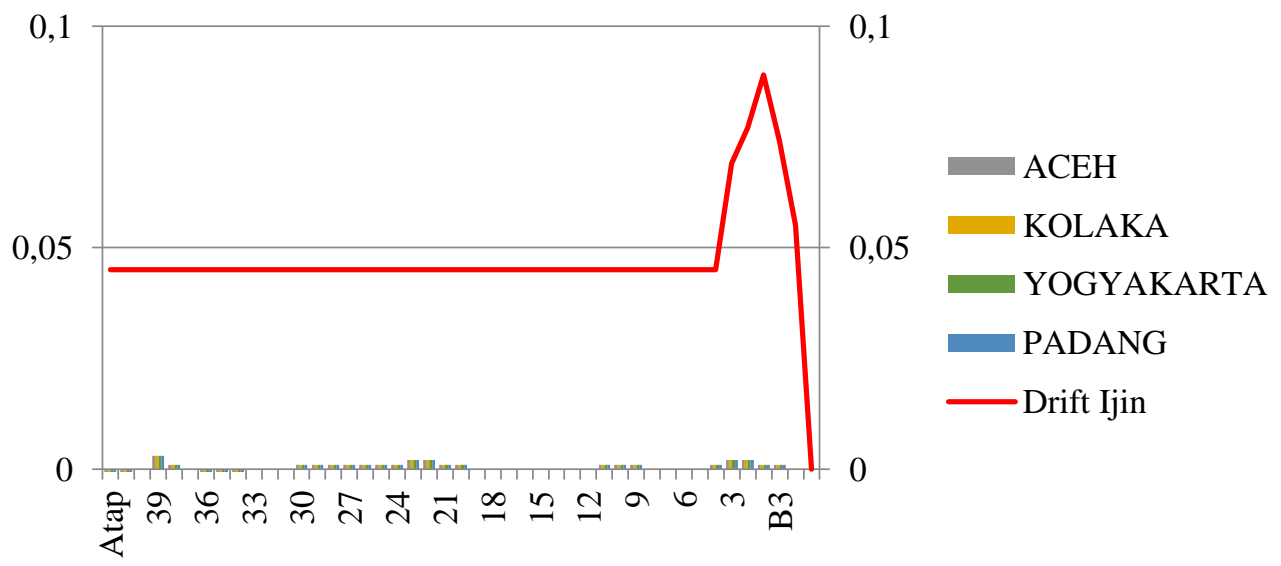

Gambar 4. Simpangan Antar Lantai Arah X Bangunan 41 Lantai

c. Gaya Geser Tingkat (Base Shear)

Gaya geser dasar merupakan penjumlahan gaya geser (V2) kolom yang berada di tingkat yang sama untuk masing-masing tingkat.

Tabel 3. Hasil Analisis Base Shear Bangunan 41 Lantai

\begin{tabular}{|c|c|c|c|c|c|}
\hline \multicolumn{2}{|c|}{ TABLE: Element Forces } & \multicolumn{4}{|c|}{ Gaya Geser Tiap Kota } \\
\hline Lantai & Output Case & Kota Aceh & Kota Kolaka & $\begin{array}{c}\text { Kota } \\
\text { Yogyakarta }\end{array}$ & $\begin{array}{c}\text { Kota } \\
\text { Padang }\end{array}$ \\
\hline Text & Text & KN & KN & KN & KN \\
\hline Atap & COM.MAX & 182,119 & 182,119 & 182,119 & 182,119 \\
\hline
\end{tabular}

Evaluasi Bangunan 41 Lantai Tahan Gempa dengan Analisis Dinamik Spektrum Respons Ragam (Mansyur) 
https://jurnal.unsulbar.ac.id/index.php/saintifik

\begin{tabular}{|c|c|c|c|c|c|}
\hline 41 & COM.MAX & 3963,774 & 3963,774 & 3963,774 & 3963,774 \\
\hline 40 & COM.MAX & 1029,029 & 1029,029 & 1029,029 & 1029,029 \\
\hline 39 & COM.MAX & 5657,990 & 5657,990 & 5657,990 & 5657,990 \\
\hline 38 & COM.MAX & 2817,070 & 2817,070 & 2817,070 & 2817,070 \\
\hline 37 & COM.MAX & 12,551 & 12,551 & 12,551 & 12,551 \\
\hline 36 & COM.MAX & 12,653 & 12,653 & 12,653 & 12,653 \\
\hline 35 & COM.MAX & 7860,586 & 7860,586 & 7860,586 & 7860,586 \\
\hline 34 & COM.MAX & 4133,208 & 4133,208 & 4133,208 & 4133,208 \\
\hline 33 & COM.MAX & 6332,353 & 6332,353 & 6332,353 & 6332,353 \\
\hline 32 & COM.MAX & 165,492 & 165,492 & 165,492 & 165,492 \\
\hline 31 & COM.MAX & 4777,328 & 4777,328 & 4777,328 & 4777,328 \\
\hline 30 & COM.MAX & 161,100 & 161,100 & 161,100 & 161,100 \\
\hline 29 & COM.MAX & 192,978 & 192,978 & 192,978 & 192,978 \\
\hline 28 & COM.MAX & 191,304 & 191,304 & 191,304 & 191,304 \\
\hline 27 & COM.MAX & 219,855 & 219,855 & 219,855 & 219,855 \\
\hline 26 & COM.MAX & 376,698 & 376,698 & 376,698 & 376,698 \\
\hline 25 & COM.MAX & 237,809 & 237,809 & 237,809 & 237,809 \\
\hline 24 & COM.MAX & 258,327 & 258,327 & 258,327 & 258,327 \\
\hline 23 & COM.MAX & 950,330 & 950,330 & 950,330 & 950,330 \\
\hline 22 & COM.MAX & 866,718 & 866,718 & 866,718 & 866,718 \\
\hline 21 & COM.MAX & 237,161 & 237,161 & 237,161 & 237,161 \\
\hline 20 & COM.MAX & 185,623 & 185,623 & 185,623 & 185,623 \\
\hline 19 & COM.MAX & 407,619 & 407,619 & 407,619 & 407,619 \\
\hline 18 & COM.MAX & 686,657 & 686,657 & 686,657 & 686,657 \\
\hline 17 & COM.MAX & 546,930 & 546,930 & 546,930 & 546,930 \\
\hline 16 & COM.MAX & 157,881 & 157,881 & 157,881 & 157,881 \\
\hline 15 & COM.MAX & 141,639 & 141,639 & 141,639 & 141,639 \\
\hline 14 & COM.MAX & 99,528 & 99,528 & 99,528 & 99,528 \\
\hline 13 & COM.MAX & 227,564 & 227,564 & 227,564 & 227,564 \\
\hline 12 & COM.MAX & 392,152 & 392,152 & 392,152 & 392,152 \\
\hline 11 & COM.MAX & 76,550 & 76,550 & 76,550 & 76,550 \\
\hline 10 & COM.MAX & 81,793 & 81,793 & 81,793 & 81,793 \\
\hline 9 & COM.MAX & 86,348 & 86,348 & 86,348 & 86,348 \\
\hline 8 & COM.MAX & 83,663 & 83,663 & 83,663 & 83,663 \\
\hline 7 & COM.MAX & 62,663 & 62,663 & 62,663 & 62,663 \\
\hline 6 & COM.MAX & 44,952 & 44,952 & 44,952 & 44,952 \\
\hline 5 & COM.MAX & 45,532 & 45,532 & 45,532 & 45,532 \\
\hline 4 & COM.MAX & 37,561 & 37,561 & 37,561 & 37,561 \\
\hline 3 & COM.MAX & 128,897 & 128,897 & 128,897 & 128,897 \\
\hline 2 & COM.MAX & 262,792 & 262,792 & 262,792 & 262,792 \\
\hline 1 & COM.MAX & 68,128 & 68,128 & 68,128 & 68,128 \\
\hline B3 & COM.MAX & 98,394 & 98,394 & 98,394 & 98,394 \\
\hline B2 & COM.MAX & 37,104 & 37,104 & 37,104 & 37,104 \\
\hline
\end{tabular}

101

Evaluasi Bangunan 41 Lantai Tahan Gempa dengan Analisis Dinamik Spektrum Respons Ragam (Mansyur) 


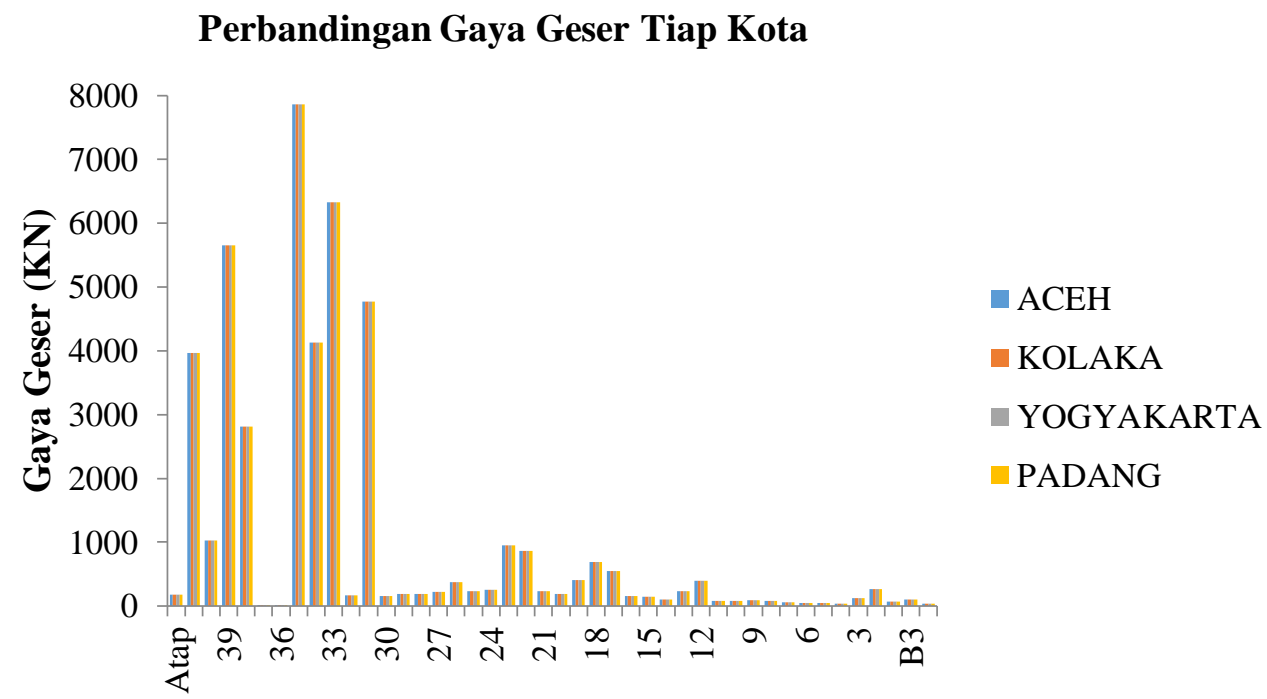

Gambar 5. Gaya Geser Tingkat Bangunan 41 Lantai

\subsection{Pembahasan Hasil Analisis}

Berdasarkan hasil analisis, didapatkan bahwa untuk tipe bangunan 41 lantai yang ditinjau dari 4 kota memenuhi kapasitas ketahanan gempa berdasarkan metode analisis dinamik ragam respons spektrum. Perbedaan terjadi pada kontrol simpangan antar lantai baik arah $\mathrm{x}$ maupun arah $\mathrm{y}$, hal ini disebabkan karena data bangunan yang ditinjau sama untuk tiap kota namun bangunan ditinjau di 4 kota yang memiliki intensitas gempa berbeda.

Perbedaan simpangan antar lantai untuk arah x terbesar di 4 kota yang ditinjau yaitu pada lantai 39. Untuk Kota Aceh memiliki nilai simpangan antar lantai 0,009 m, Kota Kolaka memiliki nilai simpangan antar lantai $0,009 \mathrm{~m}$, Kota Yogyakarta memiliki nilai simpangan antar lantai 0,009 m, dan Kota Padang memiliki nilai simpangan antar lantai 0,009 m. Sedangkan nilai simpangan antar lantai yang diijinkan tidak melebihi dari 0,045 m.

Perbedaan simpangan antar lantai untuk arah y terbesar di 4 kota yang ditinjau yaitu pada lantai 2. Untuk Kota Aceh memiliki nilai simpangan antar lantai 0,003 m, Kota Kolaka memiliki nilai simpangan antar lantai $0,003 \mathrm{~m}$, Kota Yogyakarta memiliki nilai simpangan antar lantai 0,003 m, dan Kota Padang memiliki nilai simpangan antar lantai 0,003 m. Sedangkan nilai simpangan antar lantai yang diijinkan tidak melebihi dari $0,045 \mathrm{~m}$.

Perbedaan gaya geser tingkat terbesar di 4 kota yang ditinjau yaitu pada lantai 2. Untuk Kota Aceh memiliki nilai gaya geser 7680,586 KN, Kota Kolaka memiliki nilai gaya geser 7680,586 KN, Kota Yogyakarta memiliki nilai gaya geser 7680,586 KN, dan Kota Padang memiliki nilai gaya geser $7680,586 \mathrm{KN}$.

Karena nilai simpangan antar lantai baik arah $\mathrm{x}$ maupun arah y memenuhi simpangan antar lantai yang diijinkan maka bangunan aman untuk dibangun di 4 kota yang tinjau. Semakin banyak jumlah tingkat, semakin besar perbedaannya. Nilai gaya geser pada pada bangunan yang ditinjau berpengaruh pada intensitas gempa. Semakin besar intensitas gempa pada masing-masing kota maka semakin besar nilai gaya geser. Nilai gaya geser maupun simpangan antar lantai ditinjau memiliki nilai yang sama akibat nilai beban gaya gempa lebih kecil dibanding beban mati maupun beban yang lainnya.

Rekapitulasi hasil desain yang ekonomis untuk bangunan yang ditinjau dengan peninjauan di 4 kota Indonesia adalah sebagai berikut:

Tabel 4. Rekapitulasi Hasil DesainBangunan 41 Lantai 


\begin{tabular}{|l|c|c|c|c|}
\hline Nama Kota & $\begin{array}{l}\text { Mutu } \\
\text { Beton } \\
\text { (MPa) }\end{array}$ & Ket. & $\begin{array}{l}\text { Mutu } \\
\text { Beton } \\
\text { Ekonomis } \\
\text { (MPa) }\end{array}$ & Ket. \\
\hline Kota Aceh & 55 & Aman & 55 & Aman \\
\hline Kota Kolaka & 55 & Aman & 55 & Aman \\
\hline $\begin{array}{l}\text { Kota } \\
\text { Yogyakarta }\end{array}$ & 55 & Aman & 55 & Aman \\
\hline Kota Padang & 55 & Aman & 55 & Aman \\
\hline
\end{tabular}

Adapun detail gambar gaya geser dan simpangan antar lantai terlampir pada masing-masing kota yang ditinjau

\section{KESIMPULAN}

Berdasarkan hasil analisis,didapatkan bahwa untuk tipe bangunan 41 lantai yang ditinjau dari 4 kota memenuhi kapasitas ketahanan gempa berdasarkan metode analisis dinamik ragam respons spektrum.Perbedaan terjadi pada kontrol simpangan antar lantai baik arah x maupun arah y, hal ini disebabkan karena data bangunan yang ditinjau sama untuk tiap kota namun bangunan ditinjau di 4 kota yang memiliki intensitas gempa berbeda.Nilai gaya geser maupun simpangan antar lantai yang ditinjau memiliki nilai sama akibat nilai beban gaya gempa lebih kecil dibanding beban mati maupun beban yang lainnya.

\section{DAFTAR PUSTAKA}

Afriadi Y, Satyarno I. 2013. Perbandingan spektra desain beberapa kota besar di Indonesia dalam SNI 2012 Gempa dan SNI 2002. Konferensi Nasional Teknik Sipil 7, 24-26 Oktober 2013. Surakarta (ID)Universitas Sebelas Maret. hlm 299-305.

Agus Hariyanto. 2011. "Analisis Kinerja Struktur Pada Bangunan Bertingkat Tidak Beraturan Dengan Analisis Dinamik Menggunakan Metode Analisis Respon Spektrum," Jurusan Teknik Sipil Fakultas Teknik Universitas Sebelas Maret.

Badan Standardisasi Nasional (BSN). 2012. SNI 03-1726-2012 Tata Cara Perencanaan Ketahanan Gempa Untuk Bangunan Gedung. Jakarta (ID): BSN.

Budiono B, Supriatna L. 2011. Studi Komparasi Desain Bangunan Tahan Gempa dengan Menggunakan SNI 03-1726-2002 dan RSNI 03-1726-201X. Bandung (ID): ITB Pr.

Bowles, Joseph E. Johan K. Helnim. 1991. Sifat-sifat Fisis dan Geoteknis Tanah (Mekanika tanah). PT. Erlangga. Jakarta. (Hal. 6) Craig, R.F. 1991. Mekanika Tanah. PT. Erlangga. Jakarta.

Christiawan I, Triwiyono A, Christady H. 2008. "Evaluasi kinerja dan perkuatan struktur gedung guna alih fungsi bangunan. Studi kasus: perubahan fungsi ruang kelas menjadi ruang perpustakaan pada lantai II gedung G Universitas Semaran,". Forum Teknik Sipil. vol. 18(1), pp. 725-738.

Elliza, Ismailah Nur. 2013. "Evaluasi Kinerja Struktur Pada Gedung Bertingkat dengan Analisis Respon Spektrum MenggunakanSoftware ETABS V 9.50 (Studi Kasus : Gedung Solo Center Point), Jurusan Teknik Sipil, FakultasTeknik Universitas Sebelas Maret, Surakarta.

Helmy, Iskandarsyah. 2009. "Analisis Respon Spektrum pada Bangunan yang Menggunakan Yielding Damper Akibat Gaya Gempa", Departemen T Sipil Fakultas Teknik Universitas Sumatera Utara, Medan. 
https://jurnal.unsulbar.ac.id/index.php/saintifik

Purnomo W. 2015. "Perencanaan Struktur Gedung Bank 4 Lantai Tahan Gempa dengan Sistem Daktail Penuh di Wilayah Gempa 3". Universitas Muhamadiyah Surakarta.

Sayed A.F., Erizal, Asep S. 2018. "Evaluasi Ketahanan Gempa pada Struktur Gedung X di Jakarta Berdasarkan SNI 03-1726-2012,” Jurnal Teknik Sipil dan Lingkungan, vol. 3(1), pp. 11-24. 